MEDICAL ETHICS

\title{
Professional-patient relationships and informed consent
}

\author{
N G Messer
}

Postgrad Med J 2004;80:277-283. doi: 10.1136/pgmj.2003.012799

Four theoretical ethical perspectives on professional-patient relationships-autonomy, justice, virtue ethics, and the ethic of care-are surveyed, and some of their implications for the informed consent requirement in health care are sketched out. The practical issues of competence to consent, adequate information, and voluntariness are reviewed, and examples are given of the ways in which the theoretical perspectives outlined earlier might inform practice in areas such as these. Finally, the situation of patients not competent to consent is considered in the light of the same theoretical perspectives.

$\mathrm{T}$ his review is an attempt to show how a variety of theoretical approaches to ethics may inform, and be informed by, the practice of professional-patient relationships and informed consent. Given the extent of the subject, the treatment of it here is inevitably illustrative rather than comprehensive. Also, while referring occasionally to legal discussions, it will not deal in any detail with the law governing informed consent and related topics: for a full treatment, the reader is referred elsewhere. $^{1-3}$

\section{IMPORTANCE OF INFORMED CONSENT}

Though the historical evidence is somewhat ambiguous, informed consent in the sense in which it is understood and practised today appears to be a relatively recent arrival in medical ethics (Faden and Beauchamp, p 53-113). ${ }^{4}$ Legal judgments enshrining an informed consent requirement have built up since the early 20th century (Faden and Beauchamp, chapter 4), ${ }^{45}$ and it is now widely assumed to be central to professional-patient relationships and health care $^{6}$ (although it is still a matter of controversy whether as currently practised it amounts to a "meaningful [exercise] of informed choice by patients" (Faden and Beauchamp, p 100)). ${ }^{4}$

Several factors have contributed to this assumption about the centrality of informed consent, including the awareness of past abuses and controversial cases, ${ }^{7}$ the growth of the patients' rights movement (Faden and Beauchamp, p 93ff) ${ }^{4}$ and perhaps a growing consumerist attitude to medicine. ${ }^{8}$ Recent causes célèbres such as the Alder Hey affair ${ }^{9}$ in the UK have once again placed informed consent centre stage.$^{10}$ Yet its importance is more often assumed than stated: it is therefore worth examining the consent requirement in the context of health care professional-patient relationships and asking why it is important (if indeed it is). In reviewing some possible answers to this question, it may be possible to shed some light on the practice of informed consent and on some of its problems.

\section{(1) Autonomy, principlism, and informed consent}

The standard justification of informed consent is that it is an essential safeguard of patient autonomy, where "autonomy" means something like "a capacity for independent decisions and action" (p 23). ${ }^{11}$ Autonomy is often linked to the philosophy of Kant ${ }^{12}$ or Mill, ${ }^{13}$ but probably the most influential account in health care ethics comes from the "principlist" approach of Beauchamp and Childress. ${ }^{14}$ They claim that the four principles of respect for autonomy, nonmaleficence, beneficence, and justice are part of a "common morality" shared by "all morally serious persons" (p 3), ${ }^{14}$ whatever the underlying philosophical or religious commitments of those persons. Practical moral decision making involves a process of specification of the principles' implications in the particular situation in view, and balancing the relative importance of the principles if they conflict (p l-25)..14 While principlism has become a standard approach to health care ethics, it continues to be the subject of some controversy. ${ }^{15} 16$

If autonomy is held to be a key concept, the most appropriate way to understand the professional-patient relationship may be to think of it as a kind of contract. Admittedly, this connection is not made by many advocates either of autonomy (Beauchamp and Childress, p 57112), ${ }^{14}$ or of the contractual model: indeed, the latter is sometimes presented as a rival to a principles based approach. ${ }^{17}$ However, a strong connection between autonomy and contractual approaches can arguably be made: by understanding the relationship as a contract, advocates of this model seek to place professional and patient on an equal footing, spell out the legitimate expectations that each can have of the other, and empower the patient to play an active part in decision making about her treatment. ${ }^{18}$ All of these are standard features of accounts of autonomy in health care ethics. And the signing of the consent form, the "modern clinical ritual" of consent, ${ }^{19}$ readily lends itself to interpretation in contractual terms.

As William F May argued some years ago, a contractual model of professional-patient relationships has obvious advantages over paternalistic models, but nonetheless has significant flaws and dangers. It can encourage either a "self interested minimalism" that fulfils the letter of the contract but no more, or a defensive "maximalism" that performs every possible test and procedure, however marginal or unlikely the 


\section{Box 1: The importance of informed consent}

- Among the possible arguments for informed consent are:

- That it safeguards patient autonomy.

- That it is a requirement of justice, understood in terms of patient empowerment.

- That it is a central feature of the covenant relationship between professional and patient, expressing the professional virtue of fidelity.

- A supplement and corrective to mainstream accounts of professional-patient relationships that focus on autonomy and justice is offered by a care approach which calls for qualities such as "sympathetic understanding".

benefit. ${ }^{20}$ Furthermore, the maxim "let the buyer beware" is unrealistic in clinical encounters (Campbell et al, p 22), ${ }^{18}$ another reason for thinking that "contract" may not be the most appropriate model for such relationships.

\section{(2) Justice and empowerment}

Onora O'Neill suggests (p 4) that the stress on individual autonomy in medical ethics may have marginalised issues concerned with justice. ${ }^{11}$ A related theme has been developed by Karen Lebacqz (p 133), ${ }^{21}$ who argues that professionalpatient relationships must be understood in terms of patient empowerment, or "advocating for oneself and participating maximally in significant decisions" (citing Kapp ${ }^{22}$ ). While such a definition has obvious links with autonomy, Lebacqz develops her account in terms of another of Beauchamp and Childress' principles, justice. Drawing on the experience of Oliver Sacks, ${ }^{23}$ she shows how even someone who is relatively privileged can be disempowered in the clinical setting both by his physical injury and by the accompanying "loss of status [and] diminished sense of personhood" (p 135). ${ }^{21}$ However, the problem of disempowerment becomes much more profound if the patient is already marginalised as a result of race, class and/or gender, and Lebacqz claims that the empowerment of such patients requires "nothing short of a change in the system" (p 141). ${ }^{21}$

What is the role of informed consent within a clinical encounter viewed through the lens of justice as empowerment? A starting point is O'Neill's suggestion that the purpose of the consent requirement is to provide "reasonable assurance that the patient ... has not been deceived or coerced". ${ }^{6}$ However, the mere signing of a consent form may not itself provide this reasonable assurance ( $\mathrm{O}^{\prime}$ Neill, p 26-7) ${ }^{1{ }^{11}}$ Careful and appropriate communication is needed to ensure that a formal consent procedure does indeed indicate "[maximal participation] in one's own significant decisions". ${ }^{21}$ What constitutes careful and appropriate communication will be considered further below. The problems of consent which came to light at Alder Hey indicate that this issue is not confined to history. ${ }^{6}$ And if a patient is highly disempowered on account of race, class and/or gender, the "ritual" of informed consent may be rendered an empty one: in the perspective of justice as empowerment, broader questions of institutional structures and access to health care are closely linked to those of the individual professional-patient encounter (Lebacqz, p 144-6). ${ }^{21}$

\section{(3) Virtue and covenant}

One of the most important developments in ethical theory in recent decades has been the renewal of interest in the ancient theory of the virtues. The recent revival of virtue theory began with the work of Elisabeth Anscombe, ${ }^{24}$ though perhaps its best known exponent is Alasdair MacIntyre. ${ }^{25}$ MacIntyre has argued that modern approaches to ethics (such as Kantian and utilitarian theories) are bound to fail because they are attempts to give a rational justification for the language and concepts of morality in isolation from the coherent moral and intellectual tradition within which those concepts were originally located-the tradition of the virtues, which can be traced back to Plato, Aristotle, and their predecessors. This virtue based critique is sometimes levelled, not only at Kantian and consequentialist ethical theories, but also at principlist approaches. ${ }^{8}$

A virtue approach holds that our character-the sort of people we are-is more fundamental to ethical reflection than our individual decisions or actions: "An action is right if and only if it is what an agent with a virtuous character would do in the circumstances" (Oakley, p 88). ${ }^{8}$ But how do we know what constitutes a virtuous character? On many recent accounts, the virtues are character traits necessary for a flourishing or fulfilled life. $^{86}$ Some writers, such as MacIntyre, stress the importance of a community with a shared narrative and tradition in giving an account of the virtuous life. ${ }^{25}$ Virtue theory has been used extensively by some Christian theological writers on medical ethics, ${ }^{27}$ though by no means all contemporary accounts of the virtues are tied to Christian theology. ${ }^{28}$

A virtue based account of professional-patient relationships will be concerned with the character both of the health professional and of the patient. For example, May identifies three essential virtues of doctors: prudence (which includes both scientific understanding and skill in the art of healing), fidelity to the patient, and the public spiritedness that leads professionals to cooperate in teams, institutions, and professional bodies for the sake of the public good. ${ }^{29}$ Some writers have attempted to characterise the core virtues of patients, such as patience, fortitude, and hope..$^{30}$ The contrast between virtue based and principlist approaches should not be overstated: some advocates of each acknowledge at least some place for the other. ${ }^{14}{ }^{29}$

Some writers, such as May, have linked a virtue ethics approach with an understanding of the professional-patient relationship as a covenant. ${ }^{29}$ Covenant is a religious and moral concept with roots in the Hebrew and Christian scriptures, where it denotes a solemn and binding agreement between God and his people, ${ }^{29}$ or between human beings. There are obvious similarities between covenants in the latter sense and contracts, and some authors hold that a contractual model of professional-patient relationships can express the essential meaning of covenant in secular terms. ${ }^{17}$ However, covenant is better understood as an alternative to contract: a model which portrays professional-patient relationships as richer, deeper, and more open ended than does the latter, and which is less susceptible to "self interested minimalism" and defensive "maximalism". ${ }^{18} 2032$

On a covenantal understanding, the informed consent requirement can be understood as an expression of the professional virtue of fidelity. This theme was foreshadowed in 1970 by Paul Ramsey, who advocated a covenantal approach, arguing that the fundamental ethical question was, "What is the meaning of the faithfulness of one human being to another in every one of these relations?" (p xii). ${ }^{7}$ Although Ramsey did not explicitly use the language of virtue, his use of "faithfulness" as a central ethical category fits well with May's more recent exposition of fidelity as a key virtue of the medical profession. Ramsey described the consent requirement as "the cardinal canon of loyalty joining men together in medical practice and investigation" (p 5). ${ }^{7}$ Paraphrasing Reinhold Niebuhr, he identified both positive and negative reasons for its importance: "man's capacity to become joint 
adventurers in a common cause [such as the curing of disease or the advancement of understanding through research] makes the consensual relation possible; man's propensity to over-reach his joint adventurer even in a good cause makes consent necessary" (p 5-6). ${ }^{7}$

This suggests that there should be a dual aspect to the practice of informed consent. If the consent requirement is a safeguard against distortions and abuses of the medical covenant, robust formal consent procedures must be in place and rigorously observed. Presumably these will include the signing of consent form (though as observed earlier, a signed consent form is no guarantee of an effective or valid consent) (p 6). ${ }^{6}$ But if consent is an expression of fidelity in the medical covenant, it must be seen as part of an open ended relationship in which clinical decisions are made in the course of honest, open, and free dialogue between patient and professional (Messer, p 13). ${ }^{32}$ Such a relationship, according to May, should be "transformational, and not merely transactional": responsive "not simply to the patient's self-perceived wants but to his or her deeper needs" (p 37)..$^{29}$

The covenant model has been criticised for failing to deliver on its promise of a richer account than the contractual model, and for having too narrow a religious base to be of use in pluralist societies. ${ }^{17}$ However, Campbell et al hold that it can articulate a sense of medical vocation understood in religious or humanistic terms..$^{18} \mathrm{~A}$ further danger is that the covenant model advances an over-idealised picture of the health professional, which makes unrealistic and perhaps harmful demands on the professional and risks reopening the door to paternalism. ${ }^{18} 2933$ According to May (p 145-68), an understanding of health professionals as "teachers" of their patients offers some safeguard against these dangers ${ }^{20} 29$; this will be discussed further in a later section.

\section{(4) The ethic of care}

Another critique of mainstream modern ethical theory is to be found in the "ethic of care". This approach, as a formal theory, originates in the work of the psychologist Carol Gilligan, ${ }^{34}$ who claimed that men and boys tend to approach moral problems in terms of principles, rules, and rights (the "voice of justice"), whereas women and girls typically place more emphasis on relationships, empathy, and responsibility (the "voice of care"), though neither "voice" is restricted to one or other gender (Beauchamp and Childress, p 371). ${ }^{14}$ Gilligan's theory has been supported and complemented by others such as Nel Noddings. ${ }^{35}$

An ethic of care is obviously relevant to professionalpatient relationships. Rita Manning identifies five characteristics of this approach: (1) moral attention to "the situation in all its complexity"; (2) sympathetic understanding which is willing to identify with the persons in the situation and seeks to become aware of their wishes and best interests; (3) relationship awareness that is sensitive to the network of human relationships in which we all participate, and to particular relationships and roles such as those of professional and patient; (4) attempting to accommodate as fully as possible the needs and interests of all those involved in a situation; and (5) response to the needs of others in caring action. $^{36}$ Some versions reject any appeal to universal principles, rules, or norms (Noddings, p 79-103), ${ }^{35}$ and have accordingly been criticised for being parochial, arbitrary, and capricious. ${ }^{37}$ Other advocates of care hold that the "care voice" and the "justice voice" can and should be combined, perhaps by regarding respect for rights as a minimum moral standard, and care as the moral ideal. ${ }^{36}$

A number of authors have used a care approach extensively in developing nursing ethics (Kuhse, p 143-66). ${ }^{37}$ However, critics point out the danger of reinforcing traditional gender roles and stereotypes, and supporting the subordination of women to men and nurses to doctors (Kuhse, p 162-6). ${ }^{37}$ Such an identification could also obscure our common obligation to care, whatever our gender or professional role: structures that confine the caring role to one particular group are to be criticised. ${ }^{36}$ It is perhaps best, therefore, to understand the ethic of care as offering an important corrective to the imbalances in mainstream approaches (Beauchamp and Childress, p 375-6). ${ }^{14}$ A care approach has obvious common ground with covenant (Messer, p 8-10) ${ }^{32}$ and virtue ${ }^{38}$ approaches.

\section{PRACTICE OF INFORMED CONSENT}

This section will briefly discuss some practical aspects of informed consent. Medical treatment and research are the subjects most extensively covered in the literature on consent, but other increasingly problematic areas are organ and tissue procurement (both from living and from cadaveric "donors"), ${ }^{39}$ the use of patient information, for example in communicable disease surveillance, ${ }^{40}$ and public health measures such as vaccination programmes. ${ }^{41}$

Various important distinctions can be made between varieties of consent. Beauchamp and Childress (p 65-6) distinguish between express, tacit, implicit, and presumed consent. ${ }^{142}$ Express consent (for example, given by the signing of a consent form) is the paradigm for health care and clinical research. Tacit consent is given by a failure to dissent from a proposed course of action. Implicit consent is inferred from the patient's decisions or actions. Presumed consent, an assumption about the decision a person would make if she were capable of consenting, is the furthest from the paradigm, and morally the most problematic ( $p$ 66). ${ }^{14}$ However, each of these types has some role in health care. Another distinction is between generic and specific consent. O'Neill notes the controversy, provoked in part by the Alder Hey case over whether one generic statement can indicate valid consent to a range of different procedures, or whether a specific consent must be obtained for each individual procedure. ${ }^{6}$

The conditions for a patient's consent to be valid are frequently summarised as competence, adequate information, and voluntariness. ${ }^{1}$ Each will be discussed in turn.

\section{(1) Competence}

"Competence" is both a medical and a legal issue: a distinction is sometimes made between the medical judgment of a patient's capacity to consent and the legal judgment of his competence; however, in practice the two are closely linked (Beauchamp and Childress, p 69), ${ }^{14}$ and hereafter "competence" will be used to refer to the medical as well as the legal judgment. Its basic meaning is "the ability to perform a task" $(\mathrm{p} 70)^{14}$ and in this context, to make

\section{Box 2: Conditions for valid consent}

- Competence, assessed by criteria such as the ability to understand the proposed action, to appreciate its significance, to reason about it, to choose and to express that choice.

- Adequate information, which requires that attention be paid to good communication between professional and patient and to problems such as the "opacity" of consent.

- Voluntariness, bearing in mind the possibility of subtle as well as blatant forms of controlling influence, particularly in the case of vulnerable individuals or groups. 
decisions about one's own health care, participation in research, etc. Competence varies from one task to another (for example, a person may be incompetent to manage his own financial affairs, but still competent to decide on his participation in clinical research) and changes over time (children become competent as they mature, and adults may become temporarily or permanently incompetent) (p 70)..$^{14}$ There is some debate about the appropriate criteria for judging a person competent. A typical list might include the ability to understand information relevant to the decision, to appreciate its significance for one's own life and situation, to reason using relevant information, to choose and to express ${\text { one's choice. }{ }^{14} 43-45}^{-14}$

Different theoretical accounts of professional-patient relationships and informed consent may have relatively little to say about the choice of tests for competence, though Beauchamp and Childress comment on the close affinity between their accounts of competence and autonomy (p 72). ${ }^{14}$ These accounts have more to say about what should be done, and why, when patients are incompetent to consent, which will be discussed in the next main section.

\section{(2) Information}

Valid consent requires that the patient has adequate information about the proposed course of action, its probable consequences, possible alternatives and their consequences, and so on. This can be understood as a requirement both of autonomy and of justice. It implies some kind of moral obligation on professionals to disclose the necessary information to their patients, though the nature and extent of the legal obligation varies from one jurisdiction to another. ${ }^{1446}$ The moral requirement is simply enough stated, but conceals much complexity and ambiguity. For example, how much information is required for an adequately informed consent? More is not necessarily better: "The inclusion of excessive or technical detail ... will eventually overtax even the most energetic, and undermine the possibility of informed consent" (O'Neill, p 5). ${ }^{6}$ Some patients may wish for more information than others, and the situation faced is also relevant: a patient with a painful fracture may need a shorter and crisper explanation than a woman facing the prospect of a hysterectomy, or a man and orchidectomy. Various criteria have been proposed as both legal and moral standards for adequate disclosure, including the "reasonable doctor" standard, the "reasonable person" standard and the "subjective" standard (what this particular person, rather than a hypothetical "reasonable person", considers adequate) (Beauchamp and Childress, p 81-3). ${ }^{14}$ The last has something in common with $\mathrm{O}^{\prime} \mathrm{Neill's}$ recommendation to give patients "a limited amount of accurate and relevant information and [provide] user friendly ways for them to extend this amount" (p 6). ${ }^{6}$

O'Neill highlights a further problem, the "opacity" of consent. Suppose that a patient consents to procedure A, which logically entails $B$ and has the likely consequence $C$. If the patient is ignorant of the connections between $\mathrm{A}, \mathrm{B}$ and $\mathrm{C}$, she has not given her informed consent to $\mathrm{B}$ or $\mathrm{C}$, even though professionals, to whom the connections are obvious, may assume that she has. In the Alder Hey case, for example, some parents consented to the retention of tissue from their children, but did not believe they were thereby consenting to the removal of organs. ${ }^{6}{ }^{9}$

As noted earlier, May argues that a covenantal model of professional-patient relationships "demands that healers teach their patients" (p 145). ${ }^{20}$ His account of "teaching" goes beyond the mere disclosure of information, touching on matters such as health education in preventive medicine and appropriate ways of communicating with terminally ill patients (p 145-68). ${ }^{20}$ He argues that the educational role of health professionals is an important safeguard against paternalism in the medical covenant (p 37-8). ${ }^{29}$ Clearly, education itself can be oppressively paternalistic, but it can also have enormous power for empowerment and transformation. ${ }^{47}$

Some of what May says about teaching could be reinforced by a care approach, in which "sympathetic understanding", "relationship awareness", "accommodation", and the other core ideas of an ethic of care have obvious implications for communication between professionals and patients (p 989). ${ }^{36}$ The difficulty, of course, as both May ( $p$ 146) $)^{20}$ and Manning ( $\mathrm{p} 103)^{36}$ in effect acknowledge, is that good communication takes time and effort, and may seem impossibly idealistic when resources are limited and health care systems embody other priorities. (While appropriate patient information literature can help bridge this gap, it is unlikely to be a complete solution: the kind of communication envisaged by May and Manning requires personal interaction that may be costly in professionals' time and energy.) At this point, the ethical discussion of professionalpatient relationships and informed consent comes into contact with other ethical and political questions about the allocation of resources and the organisation of health care delivery.

\section{(3) Voluntariness}

"[A] person acts voluntarily to the extent that he or she wills the action without being under the control of another's influence" (Beauchamp and Childress, p 93). ${ }^{14}$ On this definition, voluntariness can be compromised by various forms of controlling influence, including coercion (the threat of force or harm) and manipulation. Of course, not all forms of influence are either controlling or unwelcome ( $p$ 94). ${ }^{14}$

In a clinical setting, voluntariness may be fragile because of the vulnerability of the patient, the imbalance in knowledge and power between professional and patient and, for some patients, a measure of dependency on the professional. When patients are particularly vulnerable in these ways, what professionals construe in good faith as rational persuasion may unintentionally exert undue influence: care needs to be taken to ensure that particularly passive, dependent, or anxious patients' decision making is truly voluntary (p 967). ${ }^{14}$ Undue influence can also be brought to bear, often with the best of intentions, by third parties-for example, family members may pressure a patient into agreeing to a course of treatment which he himself does not favour (Young, p 444). ${ }^{5}$

Voluntariness is of even greater concern in other consent situations, such as participation in research and organ or tissue donation. For example, a dependent relationship between patient and professional might lead some patients to feel obliged to volunteer for a research project, or to fear mistakenly that their medical care will be adversely affected if they refuse. Consent procedures and patient information resources need to be carefully scrutinised to ensure, as far as possible, that patients understand that their decision is voluntary, will not influence their medical care, and that their consent can be withdrawn at any time. ${ }^{48}$

There are other specific issues relating to the voluntariness of research participation or organ donation. One is the question of payment, whether in money or in kind (Kennedy and Grubb, p 733-4). ${ }^{1}$ The concern is that if the rewards promised are sufficiently great, subjects or donors may be induced to accept risks or burdens that they would otherwise consider unjustified. This could also have the effect of disproportionately attracting the poor to volunteer, which could be seen as a form of exploitation. ${ }^{49}$ Related concerns are sometimes expressed about the practice of conducting clinical trials in developing countries, particularly related to life threatening conditions like AIDS. Participation in a trial may 
offer the only opportunity for many patients to obtain medication or even routine medical care. Such situations present a significant risk of exploitation, and call for particularly careful consideration of issues such as consent, standards of care during the trial, and the care offered to participants and the wider community once the trial is completed. ${ }^{50}$

Another issue is the recruitment of research subjects or donors from institutions with powerful authority structures, such as prisons and the military. For example, de Castro describes a controversial proposal in the Philippines for prisoners to be given reductions in sentences, or commutation of death sentences, if they donate kidneys. ${ }^{51}$ Situations like this illustrate the danger that the decision to become an organ donor or a research subject, if made in such circumstances, could be subject to coercion or other forms of controlling influence. One possible response is that people in such situations should never be recruited as subjects or donors. Another is that voluntary consent in these circumstances is not impossible, and it would therefore be unduly paternalistic to ban all such recruitment, but that great care needs to be taken to avoid undue influence (Kennedy and Grubb, p 734; Ramsey, p 40-4). ${ }^{1751}$

\section{PATIENTS NOT COMPETENT TO CONSENT}

When patients are not competent to give or refuse consent to clinical procedures, others must decide on their behalf. Three questions then arise: (1) Who should decide? (2) By what criteria should they decide? (3) What are the limits of surrogate decision making?

\section{(1) Who should decide?}

The legal answer to this question can be complex, and varies from one jurisdiction to another. For example, in English law, parents or the courts can give proxy consent to the treatment of children (though doctors are not always bound by parental decisions) (Kennedy and Grubb, p 185-6), ${ }^{1}$ but at the time of writing, proxy consent for incompetent adults has no legal status ( $\mathrm{p} 228$ ). ${ }^{1}$ (This situation will be changed, however, by the implementation of the European Union Directive on Good Clinical Practice in Clinical Trials in May 2004, which will mean that consent from an incompetent adult's "legal representative" is required for participation in a clinical trial..$^{52}$ ) Ethically, it is often argued that the close family of the patient should make surrogate decisions, unless there are

Box 3: Issues concerning surrogate decision making

- Who should decide? It is often argued that surrogate decisions should normally be made by the family, and in particular, that parents should be the normal surrogate decision makers for their children.

- By what criteria? A common hierarchy of standards or guidelines is: first, the patient's own advance directive, if available; second, "substituted judgment" whereby the surrogate tries to put him/herself in the patient's shoes; third, when this is impossible, the patient's best interests.

- What are the limits of surrogate decision making? Some have argued that only therapy and therapeutic research can be authorised by a surrogate decision maker; others, that an incompetent patient's best (nonmedical) interests can be served by surrogate authorisation of non-therapeutic research or organ/tissue donation. specific reasons that disqualify them..$^{53}$ In particular, parents should normally decide for incompetent children, in part because parents are likely both to care deeply about their children and to have a better understanding than others of their needs. ${ }^{54}$ This line of argument can be defended in terms of the four principles, particularly beneficence, but might be reinforced by some of the other perspectives discussed above, particularly covenantal and care approaches. An emphasis on justice might enter the caveat (which need not be absent from other accounts) that family members making surrogate decisions must take great care to ensure that the patient's, not decision makers', needs are paramount in determining the decision. There can of course be cases where it is very difficult to disentangle the patient's from the family members' needs, and family members may need sensitive help from professionals to do so.

\section{(2) By what criteria?}

Some authors outline a hierarchy of criteria for guiding surrogate decisions: (i) advance directives-a previous competently made decision by the patient should be respected; (ii) substituted judgment—if no valid expression of the patient's wishes is available, decision makers should try to judge what the patient would have decided were she competent to do so, on the basis of their knowledge of the patient and her aims and values; (iii) best interests-where such knowledge is unavailable (for example, if the patient has never been competent), the decision should be in the patient's best interests. ${ }^{43} 54$ All these criteria are problematic to varying extents.

(i) Apart from the well known practical problems with advance directives (Beauchamp and Childress, p 100-2),,$^{14}$ their validity may be called into question by the argument that the patient may in some important sense not be the same person that she was when the directive was given. ${ }^{435}$ However, some of the approaches outlined above, particularly a virtue approach, may lend support to the commonsense notion that a person's identity over time, while subject to change, growth and decay, nonetheless has an essential continuity and unity about it (MacIntyre, p 204-5). ${ }^{25}$

(ii) It is sometimes argued that the concept of substituted judgment and related concepts like proxy consent are fictions that would be better discarded (Beauchamp and Childress, p 99-100). ${ }^{1456}$ If so, "substituted judgment" decisions will collapse either into "advance directive" or "best interest" decisions, depending whether the patient left any valid expression of her wishes (p 99-100). ${ }^{14}$ This argument is reasonably convincing if persons are regarded primarily as isolated, autonomous individuals. However, some of the approaches discussed earlier (particularly covenant and care) might support "relational" understandings of personhood which would make the notions of substituted judgment and proxy consent more coherent. ${ }^{57}$ For example, it might be possible to give an account of "sympathetic understanding" (Manning, p 98) ${ }^{36}$ which was hospitable to these concepts. And in the religious traditions within which the concept of covenant developed, the idea that one person can, as it were, stand in another's shoes is not unfamiliar: for example, in some Christian baptismal rites, godparents literally answer for the infant being baptised.

(iii) In connection with the best interests standard, some authors have raised the problem of the "moral imagination": discerning another's best interests requires us to imagine what it would be like to be that person, which in some cases may be difficult (say if the patient has a severe learning disability) or even impossible (if she has never been conscious)..$^{43}$ These difficulties must be acknowledged, but help might once again be available from the ethical perspectives discussed earlier. For example, a virtue approach 
might be able to give an account of human flourishing that can support conclusions about the best interests of patients whose lives are very different from ours; such an account may also turn out to be more accepting of difference than some of our common intuitions about lives worth living. ${ }^{59}$

(3) What are the limits of surrogate decision making? Three scenarios may be considered: medical treatment, clinical research, and organ or tissue donation from a living donor. (Cadaveric organ or tissue procurement raises other questions such as who if anyone "owns" a cadaver, and whether persons can be said to have interests that persist beyond their death: for discussion of these, the reader is referred elsewhere. ${ }^{39}$ )

Ramsey famously argued, on the grounds of covenant fidelity, that it is only morally permissible for parents to authorise medical treatment that is in the child's best interests. Participation in research and organ or tissue donation are altruistic acts that a person can only properly authorise for himself. However, he included therapeutic research in his category of treatment, where an experimental therapy offers a better balance of risk and benefit than established therapies ( $p$ 11-19). ${ }^{7}$ A similar argument could be made on the principle of beneficence. If the "best interests" test is the one that applies (if there is no indication available of the patient's actual or likely wishes), surrogate decision makers should only authorise participation in research if it promises as great, or greater, benefits than established treatments: if, for example, there is genuine equipoise between the arms of a randomised controlled trial comparing established and experimental therapies. Nontherapeutic research, it could be argued, inevitably exposes the patient to risks and burdens, with no significant prospect of benefit, and should not therefore be authorised by a surrogate decision maker. (It should be noted that Miller and Brody have recently called into question the notions of clinical equipoise and therapeutic research, arguing that research and therapy have fundamentally different intentions, and should be assessed by different ethical criteria. ${ }^{60}$ )

Others, however, argue that non-medical benefits may justify children's participation in research or their donation of organs or tissues. For example, participating in research may help a child's moral development by teaching him to act for the benefit of others (Brock, p 89-90), ${ }^{54}$ or children may benefit psychologically from knowing that their donated organ or tissue has saved a sibling's life (Elliott, p 456-7). ${ }^{43}$ Elliott, however, comments on the "notably ad hoc feel" of some of these arguments, and sounds a cautionary note about "involuntary 'altruism"'.43

A more relaxed interpretation of the "best interests" test is that surrogate decision makers may authorise a procedure that is not against the patient's best interests (Kennedy, p 70). ${ }^{1}$ It is this argument that allows some professional guidelines to sanction non-therapeutic research involving incompetent subjects provided that the research involves no more than minimal risk (that is, the same level of risk that would be involved in everyday living).$^{61}$

\section{CONCLUSION}

This review has offered some examples of theoretical reflection, practical issues and their inter-relation in the area of professional-patient relationships. The examples illustrate that the relationship between theory and practice is a complex one ${ }^{62}$; this means that the connections made here are by no means the only possible ones, and in some cases may be surprising or contentious. However, it has been argued that they are plausible, and as such they illustrate the potential of ethical theory and practice in health care to illuminate one another.

\section{Key references}

- Beauchamp TL, Childress JF. Principles of biomedical ethics. 5th Ed. New York/Oxford: Oxford University Press, 2001

- Buchanan A, Brock D. Deciding for others: the ethics of surrogate decision making. Cambridge: Cambridge University Press, 1989.

- Department of Health. Reference guide to consent for examination or treatment. London: Department of Health, 2001. Available at: http://www.doh.gov.uk/ consent/refguide.pdf.

- Faden RR, Beauchamp TL. A history and theory of informed consent. New York/Oxford: Oxford University Press, 1986.

- Various authors. Symposium on consent and confidentiality (theme issue). J Med Ethics 2003;29:2-40.

\section{ACKNOWLEDGEMENTS}

I thank Dr Janet Messer for her help and advice in the preparation of this review, and Dr Caroline Berry for some helpful suggestions.

\section{REFERENCES}

1 Kennedy I, Grubb A. Principles of medical law. Oxford: Oxford University Press, 1998, 109-279, 495-545, 714-46.

2 Grubb A. Principles of medical law: fourth cumulative supplement. Oxford: Oxford University Press, 2001, 35-57, 81-107, 132.

3 Department of Health. Reference guide to consent for examination or treatment. London: Department of Health, 2001. Available at: http:// www.doh.gov.uk/consent/refguide.pdf (accessed 16 July 2003).

4 Faden RR, Beauchamp TL. A history and theory of informed consent. New York/Oxford: Oxford University Press, 1986.

5 Young R. Informed consent and patient autonomy. In: Kuhse $H$, Singer $P$, eds. A companion to bioethics. Oxford: Blackwell, 1998, 441-51 (see 445-7).

6 O'Neill O. Some limits of informed consent. J Med Ethics 2003;29:4-7.

7 Ramsey P. The patient as person: explorations in medical ethics. New Haven: Yale University Press, 1970:1-58.

8 Oakley J. A virtue ethics approach. In: Kuhse H, Singer P, eds. A companion to bioethics. Oxford: Blackwell, 1998, 86-97 (see 87).

9 The Report of the Royal Liverpool Children's Inquiry. London: Stationery Office, 2001. Available at: http://www.rlcinquiry.org.uk/ laccessed 15 July 2003)

10 Lachmann PJ. Consent and confidentiality-where are the limits? An introduction. J Med Ethics 2003:29:2-3.

11 O'Neill O. Autonomy and trust in bioethics. Cambridge: Cambridge University Press, 2002.

12 Kant I. Groundwork of the metaphysic of morals. Paton HJ, ed and trans. London: Hutchinson, 1948.

13 Mill JS. On liberty. Everyman edition. London: J M Dent, 1993

14 Beauchamp TL, Childress JF. Principles of biomedical ethics. 5th Ed. New York/Oxford: Oxford University Press, 2001.

15 Holm S. Not just autonomy. J Med Ethics 1995;21:332-8.

16 Gillon R. Defending "the four principles" approach to biomedical ethics. J Med Ethics 1995;21:323-4.

17 McKenny GP. Theology, ethics, and the clinical encounter. In: McKenny GP, Sande JR, eds. Theological analysis of the clinical encounter. Dordrecht: Kluwer Academic Publishers, 1994:vii-xx.

18 Campbell AV, Gillett G, Jones G. Medical ethics. 3rd Ed. New York/Oxford: Oxford University Press, 2001:21-2.

19 Wolpe $\mathbf{P}$. The triumph of autonomy in American bioethics: a sociological view. In: Devries R, Subedi J, eds. Bioethics and society: sociological investigations of the enterprise of bioethics. Englewood Cliff, NJ: Prentice Hall, 1998:38-59 (cited in ref 6:4)

20 May WF. The physician's covenant: images of the healer in medical ethics. Philadelphia: Westminster Press, 1983:116-27.

21 Lebacqz K. Empowerment in the clinical setting. Theology, ethics, and the clinical encounter. In: McKenny GP, Sande JR, eds. Theological analysis of the clinical encounter. Dordrecht, Kluwer Academic Publishers, 1994:133-47 at 133

22 Kapp MB. Medical empowerment of the elderly. Hastings Cent Rep 1989;19:5.

23 Sacks O. A leg to stand on. New York: Harper and Row, 1984

24 Anscombe GEM. Modern moral theology. Collected philosophical papers. Vol III. Oxford: Basil Blackwell, 1981:26-42.

25 Maclntyre A. After virtue: a study in moral theory. 2nd Ed. London: Duckworth, 1985

26 Hursthouse R. Beginning lives. Oxford: Blackwell, 1987:218-37. 
27 Haverwas S. Suffering presence: theological reflections on medicine, the mentally handicapped. Edinburgh: T \& T Clark, 1988.

28 Casey J. Pagan virtue. Oxford: Oxford University Press, 1990.

29 May WF. The medical covenant: an ethics of obligation or virtue? In: McKenny GP, Sande JR, eds. Theological analysis of the clinical encounter. Dordrecht: Kluwer Academic Publishers, 1994:29-44.

30 Hauerwas S, Pinches C. Practicing patience: how Christians should be sick. Christians among the virtues: theological conversations with ancient and modern ethics. Notre Dame, IN: University of Notre Dame Press, 1997: 166-78.

31 Lebacqz K. The virtuous patient. In: Shelp EE, ed. Virtue and medicine. Dordrecht: D Reidel, 1985.

32 Messer NG. The therapeutic covenant: Christian ethics, doctor-patient relationships and informed consent. Cambridge: Grove Books, 1996:11.

33 Gefenas E. A contract or an encounter? In: Evans M, ed. Advances in bioethics. Vol 4. Stamford, CT/London: JAI Press, 1998:307-20.

34 Gilligan C. In a different voice. Cambridge, MA: Harvard University Press, 1982.

35 Noddings N. Caring; a feminine approach to ethics and moral education. 2nd Ed. Berkeley: University of California Press, 2003.

36 Manning R. A care approach. In: Kuhse H, Singer P, eds. A companion to bioethics. Oxford: Blackwell, 1998:98-105.

37 Kuhse H. Caring: nurses, women and ethics. Oxford: Blackwell, 1996:152-62.

38 Campbell AV. The "ethics of care" as virtue ethics. In: Evans M, ed. Advances in bioethics. Vol 4. Stamford, CT/London: JAI Press, 1998:295-305.

39 Various authors. The supply of organs for transplantation (theme issue). J Med Ethics 2003;29:125-202.

40 Turnberg L. Common sense and common consent in communicable disease surveillance. J Med Ethics 2003;29:27-9.

41 Clements CJ, Ratzan S. Misled and confused? Telling the public about MMR vaccine safety. J Med Ethics 2003:29:22-6.

42 Childress J. Who should decide? Paternalism in health care. New York/ Oxford: Oxford University Press, 1982:80-7.

43 Elliott C. Patients doubtfully capable or incapable of consent. In: Kuhse H Singer P, eds. A companion to bioethics. Oxford: Blackwell, 1998:452-62 at 454.

44 Grisso T, Appelbaum PS. Assessing competence to consent to treatment: a guide for physicians and other health professionals. New York/ Oxford: Oxford University Press, 1998

45 Van Staden CW, Krüger C. Incapacity to give informed consent owing to mental disorder. J Med Ethics 2003;29:41-3.

46 Grubb A. Consent. In: Boyd KM, Higgs R, Pinching AJ, eds. The new dictionary of medical ethics. London: BMJ Publishing Group, 1997:56-7.
47 Freire P. Pedagogy of the oppressed. Ramos MB, trans. New York: Continuum, 1993.

48 Central Office for Research Ethics Committees (COREC). Patient information sheet and consent form guidelines. Available at: http://www.corec.org.uk/ wordDocs/pis.doc (accessed 15 July 2003).

49 Harris J. Clones, genes and immortality: ethics and the genetic revolution. New York/Oxford: Oxford University Press, 1998, 142-70 (for a discussion of this point, and argument in favour of allowing payment for organ and tissue donation).

50 Nuffield Council on Bioethics. The ethics of research related to healthcare in developing countries. London: Nuffield Council on Bioethics, 2002. Available at: http:// www.nuffieldbioethics.org/filelibrary/pdf/errhdc_fullreport.pdf (accessed 15 July 2003).

51 de Castro LD. Human organs from prisoners: kidneys for life. J Med Ethics 2003;29:171-5.

52 Department of Health. Draft guidance on consent by a legal representative on behalf of a person not able to consent under the medicines for human use (clinical trials) regulations 2003. London: Department of Health, 2003. Available at: http://www.doh.gov.uk/research/ documents/rd3/legalconsentguidancerev.doc (accessed 16 July 2003).

53 Buchanan A, Brock D. Deciding for others: the ethics of surrogate decision making. Cambridge: Cambridge University Press, 1989.

54 Brock D. Ethical issues in exposing children to risks in research. In: Grodin MA, Glantz LH, eds. Children as research subjects: science, ethics and law. New York/Oxford: Oxford University Press, 1994, 81-101 at 84-85.

55 Parfit D. Reasons and persons. Oxford: Clarendon Press, 1984:326-9.

56 Harris J. Consent and end of life decisions. J Med Ethics 2003;29:10-15.

57 McFadyen Al. The call to personhood: a Christian theory of the individual in social relationships. Cambridge: Cambridge University Press, 1990 (for one example of a "relational" account of personhood.

58 Elliott C, Elliott B. From the patient's point of view: medical ethics and the moral imagination. J Med Ethics 1991;17:173-8.

59 Hauerwas S. Community and diversity: the tyranny of normality. Suffering presence: theological reflections on medicine, the mentally handicapped. Edinburgh: T \& T Clark, 1988:211-17.

60 Miller FG, Brody H. A critique of clinical equipoise: therapeutic misconception in the ethics of clinical trials. Hastings Cent Rep 2003;33:19-28.

61 Medical Research Council. The ethical conduct of research on the mentally incapacitated. London: Medical Research Council, 1991:14, 20. Available at: http://www.mrc.ac.uk/pdf-ethics-mental.pdf (accessed 15 July 2003).

62 Rachels J. Ethical theory and bioethics. In: Kuhse H, Singer P, eds. A companion to bioethics. Oxford: Blackwell, 1998:15-23. 